\title{
Bioelements in hair of children with selected neurological disorders
}

\author{
Jan Józefczuk ${ }^{\bowtie 1}$, Wiktoria Kasprzycka², Rafał Czarnecki ${ }^{1}$ Alfreda Graczyk², Paweł Józefczuk³, \\ Magda Krzysztof ${ }^{4}$, Urszula Lampart'1, Ewa Mrozowska-Ząbek1, Weronika Surdy and Róża \\ Kwiatkowska-Graczyk
}

1Paediatric Ward with the Paediatric Cardiology Unit - Specialist Hospital of the Holy Spirit in Sandomierz, Sandomierz, Poland; ${ }^{2}$ Department of Biochemistry and Optical Spectroscopy, Institute of Optoelectronics - Military University of Technology in Warsaw, Warsaw, Poland; 3Foundation for Protection of the Immunological System „Immuno", Warsaw, Poland; “Marian Smoluchowski's Institute of Physics, Jagiellonian University, Kraków, Poland

We have analyzed concentrations of magnesium (Mg), calcium (Ca), copper (Cu), zinc ( $\mathrm{Zn})$ and iron (Fe) in hair of a group of 82 children with mental retardation, in which 9 patients suffered from epilepsy, 18 from the Down's syndrome and 55 from cerebral palsy. Girls comprised little over $50 \%$ of the patients. In the group of boys with epilepsy, we found $\mathrm{Mg}, \mathrm{Ca}, \mathrm{Cu}$ and $\mathrm{Fe}$ deficiency, and normal level of $\mathrm{Zn}$. In the group of girls with epilepsy, apart from low Fe concentration, a high level of $\mathrm{Ca}, \mathrm{Mg}, \mathrm{Zn}$, and $\mathrm{Cu}$ was noted. For girls with the Down's syndrome, a high or normal level of $\mathrm{Ca}, \mathrm{Mg}, \mathrm{Zn}$ and $\mathrm{Cu}$ was found, whereas the Fe concentration varied and presented itself in a non-characteristic way. Both groups of children with cerebral palsy, i.e. boys and girls, displayed low Fe concentration in their hair; low Cu level was found in older patients as well. In this group of patients, we also noted high concentrations of $\mathrm{Ca}, \mathrm{Mg}$ and $\mathrm{Zn}$ in girls and normal in boys. A high concentration of $\mathrm{Ca}$ in girls with cerebral palsy requires separate analysis. The obtained results could be useful as guidance in the direction and determination of the amount of possible patient nutritional supplementation.

Key words: bioelements, epilepsy, Down's syndrome, cerebral palsy, hair, children

Received: 24 June, 2016; revised: 26 January, 2017; accepted: 01 February, 2017; available on-line: 14 June, 2017

e-mail: janjose@poczta.onet.pl

Abbreviations: Mg, magnesium; Ca, calcium; Cu, copper; Fe, iron; $\mathrm{Se}$, selenium, Zn, zinc

\section{INTRODUCTION}

The group of bioelements consists of macro and micronutrients.

Macronutrients are chemical compounds whose concentration in the environment (as well as in the human body) is relatively high. Because the level of macroelements among the various types of environments and groups of organisms differs, there are different reference values (Aggett, 1985; Macioszczyk, 1987; Maathuis, 2009; Rodwell et al., 2015). In regards to the human body, a macronutrient is a chemical element whose required daily intake is higher than $100 \mathrm{mg}$ and which is necessary for the healthy development. $\mathrm{Ca}$ and $\mathrm{Mg}$ are in this group. $\mathrm{Ca}$ is an important constituent of bones, it plays a pivotal role in the muscle contraction and relaxation, and also, among other functions, it regulates the electrical conduction system of the heart. $\mathrm{Mg}$ in necessary for the formation of the bone, teeth and for normal nerve and muscle function, it regulates the function of enzymes and is related to the metabolism of $\mathrm{Ca}$ and potassium.

Micronutrients are chemical compounds that occur in very low (trace) amounts in humans and plants. The required daily intake of these elements for humans is less than $100 \mathrm{mg}$. $\mathrm{Fe}, \mathrm{Cu}$ and $\mathrm{Zn}$ are among the group of micronutrients.

Fe plays a vital role in the catalysis of enzymatic reactions, it is also an essential part of cofactors such as the heme groups that make up hemoglobin, the protein which transfers oxygen. $\mathrm{Cu}$ is involved in the redox reactions of essential metabolic processes, such as mitochondrial respiration and synthesis of melanin. $\mathrm{Zn}$, as part of many specific enzymes, plays a role in gene transcription, signal transduction and regulation of apoptosis.

A deficiency or excess of macro and micronutrients could lead to a homeostasis disorder, because these elements arenecessary not only for the developmental purposes (especially of the bone structures), but they are also part of the body fluids, enzymes, high energy compounds. Bioelements influence and regulate the activity of individual organs, as well as the whole organism.

Epilepsy is a group of neurological disorders that result from temporary incapacity of the brain, which leads to rapid electrical discharge within the brain cells. Loss of consciousness and seizures are characteristic symptoms of epilepsy. It is thought that the brain damage that occurred in the perinatal or a later period is the cause of this disease (Thurman et al., 2011).

The Down's syndrome is a congenital genetic disorder caused by the presence of additional chromosome 21 . Patients with the Down's syndrome have lower cognitive abilities than among the average healthy population, and mental retardation varies from mild to moderate (Roizen \& Patterson, 2003).

Cerebral palsy is a disease deriving from the damage to the central nervous system in the prenatal or perinatal periods, or within the next few years after birth (Gajewska, 2009).

The aim of our study was to measure the concentrations of $\mathrm{Mg}, \mathrm{Ca}, \mathrm{Zn}, \mathrm{Fe}$, in the hair of children with epilepsy, Down's syndrome and cerebral palsy and determine the basis for a possible bioelement supplementation in children with the mentioned disorders. It is important to conduct further studies, because publications on the subject of trace element concentration in patients with neurological disorders, published so far (Fung, 
2002; Lech, 2002; Hartley, 2003; Kilpinen, 2009; Lima et al., 2010; Tórsdóttir et al., 2011; Amouian et al. 2013; Kheradmand et al. 2014; Prasad et al., 2014; Saad et al., 2015; Saghazadeh et al., 2015) show ambiguous results and no clear conclusions.

\section{MATERIALS AND METHODS}

We analyzed the concentrations of $\mathrm{Mg}, \mathrm{Ca}, \mathrm{Cu}, \mathrm{Zn}$ and $\mathrm{Fe}$ in hair of a group of 82 children with mental retardation, in which 9 patients suffered from epilepsy (6 girls, 3 boys), 18 from the Down's syndrome (10 girls, 8 boys) and 55 from cerebral palsy (26 girls, 29 boys). All children within our study group suffered from moderate to profound mental retardation.

The collected test samples of hair were washed via shaking in a detergent solution (shampoo) with deionized water for 15 minutes. Afterwards, the detergent was carefully rinsed out with deionized water, and additionally, the samples were shaken in acetone for 5 minutes. Thus cleaned hair was then dried to dry matter in a dryer (in temperature of approx. $50^{\circ} \mathrm{C}$ ). The samples were then put into a desiccator for 24 hours.

These samples were then mineralized with the mixture of $65 \%$ ultra-clean acids: $\mathrm{HNO}_{3}$ and $\mathrm{HClO}_{4}$ (in the proportion of $3: 1 \mathrm{v} / \mathrm{v}$ ), and then diluted with deionized water $\left(0.06 \mu \mathrm{S} \cdot \mathrm{cm}^{-1}\right)$ to a set volume $(25 \mathrm{~mL})$. Concentration of such elements as $\mathrm{Ca}, \mathrm{Mg}, \mathrm{Zn}, \mathrm{Cu}$ and $\mathrm{Fe}$ was estimated by the means of atom absorption spectrophotometer using a flame technique called F-AAS, and a spectrophotometer manufactured by Perkin Elmer (model 2100 with flame atomizer and hollow cathode lamps). The measurement was carried out in the flame of $\mathrm{C}_{2} \mathrm{H}_{2}$ with the use of air as the oxidizing gas. The proportion of gases was $2.5 / 8$, and excitation was performed at a resonant wave length of $\lambda=422.7 \mathrm{~nm}$ for $\mathrm{Ca}, \lambda=285.2$ $\mathrm{nm}$ for $\mathrm{Mg}, \lambda=213.9 \mathrm{~nm}$ for $\mathrm{Zn}, \lambda=324.8 \mathrm{~nm}$ for $\mathrm{Cu}$ and $\lambda=248.3 \mathrm{~nm}$ for Fe. For each quantified element, the obtained results are presented as $\mu \mathrm{g}$ or ng per gram of dry matter of hair.

\section{RESULTS AND DISCUSSION}

The results obtained for each bioelement concentration $(\mathrm{Ca}, \mathrm{Mg}, \mathrm{Zn}, \mathrm{Cu}, \mathrm{Fe})$ are shown in Table 1.

In the group of boys with epilepsy, apart from normal $\mathrm{Zn}$ concentration, a $\mathrm{Ca}, \mathrm{Mg}$, Fe deficiency was noted (Table 2). Results obtained for the group of girls with the same disorder indicate increased levels of $\mathrm{Ca}, \mathrm{Mg}$, $\mathrm{Zn}$ and $\mathrm{Cu}$, while the $\mathrm{Fe}$ concentration presents itself in a non-characteristic way- ranging from high to low concentrations. (Table 3).

In the group of patients with the Down's syndrome, the hair of boys displayed a decreased level of Fe, but was characterized by normal levels of $\mathrm{Ca}, \mathrm{Mg}, \mathrm{Zn}$ and $\mathrm{Cu}$ (Table 2). The girls' hair had low or normal Mg concentration, and normal or high $\mathrm{Zn}$ levels. While the $\mathrm{Cu}$ and $\mathrm{Fe}$ concentrations varied, we have noticed the tendency for high concentrations of $\mathrm{Ca}$ (Table 3).

In the most numerous group - patients with cerebral palsy, both, the girls' and boys' hair had low Fe levels, and in the elder patients, regardless of sex, we also found decreased levels of $\mathrm{Cu}$. Concentration of $\mathrm{Ca}$ was high in girls and normal in boys, whereas levels of $\mathrm{Mg}$ and $\mathrm{Zn}$ were slightly increased in girls and normal in boys. (Table 2, 3).

Neurological disorders, leading to disability and social exclusion, are caused by perinatal, genetic or environ- mental factors. Retardation and deviation of mental and physical development coexist with lower immunity, and higher frequency of infectious and somatic diseases. The severity of the disorders depends on nourishment and absorption of nutrients. Abnormal physical and mental development (Fung, 2002) and malnutrition lower the chances of full recovery of the central nervous system and affect the child's ability to adapt to the environment.

Optimization of nutritional support, based on previous assessment of the bioelement supply in children with neurological disorders, could lead to improvement of treatment and rehabilitation effects (Kilpinen-Loisa, 2009).

According to systematic review conducted by Hartley, most children with neurological disorders have a subclinical or severe deficiency of bioelements (Hartley, 2003).

Kheradmand and coworkers (2014) in their paper compared $\mathrm{Zn}$ and $\mathrm{Cu}$ concentrations in blood serum of 70 patients with epilepsy aged from 6 months to 15 years, of whom 35 children had intractable and 35 patients had controlled epilepsy. Statistically significant $\mathrm{Cu}$ insufficiency was found in a group of patients with drugresistant epilepsy. In another study, similar group's deficiency was not significant.

Meta-analysis of 40 articles regarding the role of minerals in epilepsy and febrile seizures, brought by Saghazadeh and coworkers (2015), included the comparison of $\mathrm{Zn}, \mathrm{Mg}, \mathrm{Cu}$ and selenium (Se) concentrations in blood serum, hair, and spinal fluid in patients with epilepsy and febrile seizures. The concentration of $\mathrm{Zn}$ in untreated patients with epilepsy was significantly higher than in the control group, while concentration of $\mathrm{Zn}$ in patients with febrile seizures was lower. Concentrations of $\mathrm{Cu}, \mathrm{Mg}$ and $\mathrm{Zn}$ were within normal range in patients treated with anti-epileptic drugs, whereas children with untreated epilepsy showed low Mg and high $\mathrm{Zn}$ and $\mathrm{Cu}$ levels.

In the Prasad and coworkers (2014) study, an association of serum trace elements and minerals with genetic generalized epilepsy (GGE) and idiopathic intractable epilepsy (IIE) was investigated. 200 patients with GGE and the same number of patients with IIE took part in this study. The authors had found that children with GGE had a relevantly low $\mathrm{Ca}, \mathrm{Mg}$ and $\mathrm{Zn}$ levels. A significant decrease in $\mathrm{Zn}$ concentration was found in patients unresponsive to treatment, in comparison to patients with drug-controlled epilepsy, and also, no significant difference in $\mathrm{Ca}, \mathrm{Mg}$ and $\mathrm{Zn}$ levels were found between these two groups. Low concentrations of $\mathrm{Ca}, \mathrm{Mg}$ and $\mathrm{Zn}$ and high level of $\mathrm{Cu}$ was associated with GGE, while patients with IIE had a low $\mathrm{Zn}$ concentration. The study performed indicated a correlation of high levels of $\mathrm{Ca}, \mathrm{Mg}, \mathrm{Zn}$ and $\mathrm{Cu}$ in girls, in contrast to boys, and an increased Fe level in both groups. In the study performed by us, patients with epilepsy did not suffer from drug resistant epilepsy.

$\mathrm{Zn}$ plays an important role as a micro-element. Some research (Saad, 2015) suggests a moderately beneficial influence of $\mathrm{Zn}$ treatment in patients with IIE, therefore $\mathrm{Zn}$ supplementation could be used in the epilepsy treatment protocol, especially in patients with the drug resistant epilepsy.

In Amouian's and coworkers (2013) study, 150 children with epilepsy had total blood count, Fe, $\mathrm{Zn}, \mathrm{Mg}$ and $\mathrm{Ca}$ determined.

The $\mathrm{Mg}$ concentration was significantly low, whereas $\mathrm{Ca}, \mathrm{Fe}$ and $\mathrm{Zn}$ levels were increased.

In patients with the Down's syndrome, Tórsdóttir and coworkers (2001) assessed the $\mathrm{Cu}$ homeostasis, in- 
Table 1. Bioelements' concentration in the hair of children with neurological disorders.

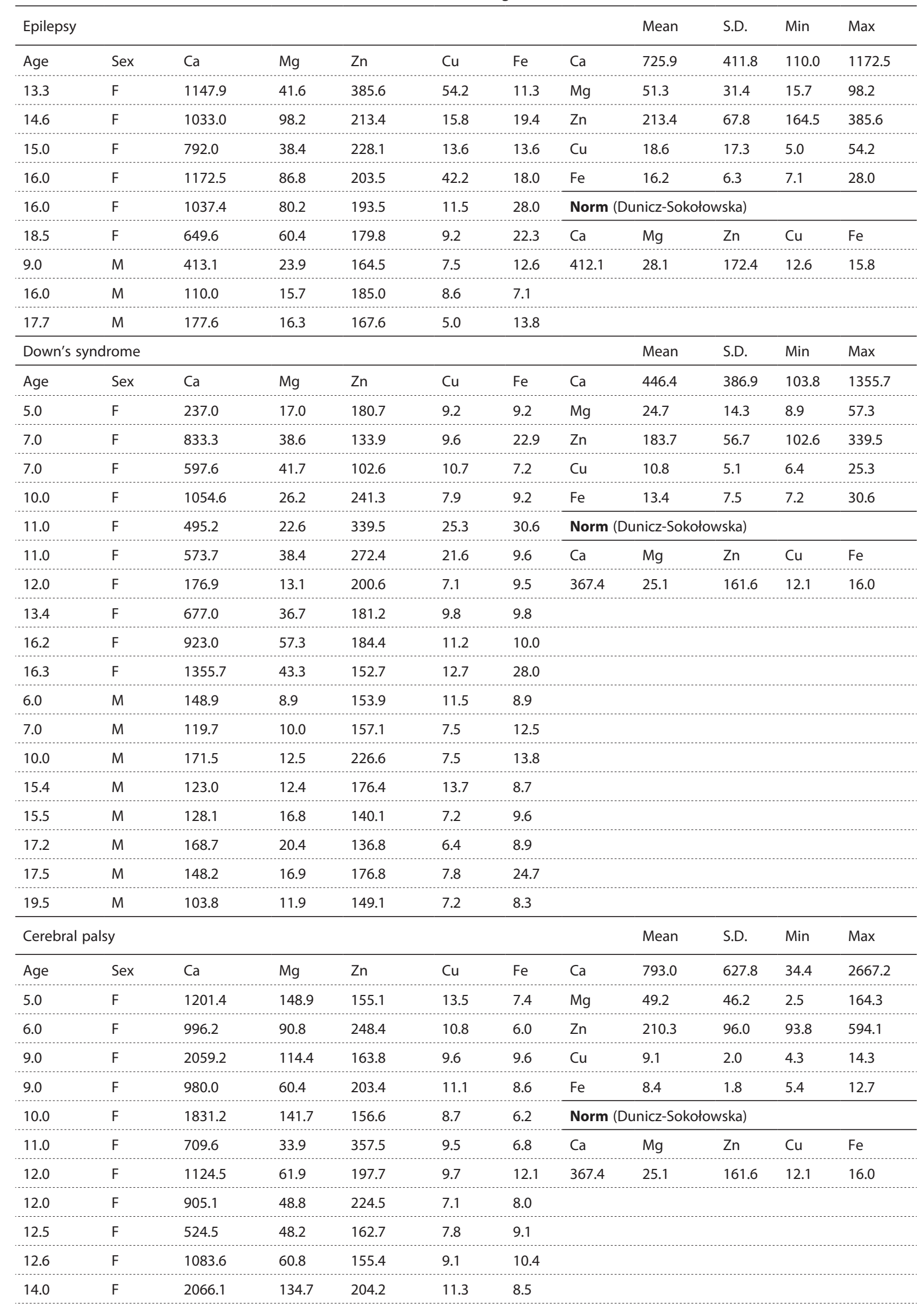




\begin{tabular}{|c|c|c|c|c|c|c|}
\hline 14.2 & $\mathrm{~F}$ & 1108.0 & 45.9 & 408.4 & 10.9 & 8.5 \\
\hline 14.5 & $\mathrm{~F}$ & 553.7 & 35.6 & 156.6 & 7.6 & 7.6 \\
\hline 15.2 & $\mathrm{~F}$ & 1403.2 & 114.0 & 140.6 & 8.9 & 8.9 \\
\hline 15.5 & $\mathrm{~F}$ & 696.5 & 37.8 & 419.8 & 8.3 & 8.3 \\
\hline 16.0 & $\mathrm{~F}$ & 2214.2 & 164.3 & 366.0 & 12.9 & 10.3 \\
\hline 16.1 & $\mathrm{~F}$ & 1046.0 & 21.3 & 305.3 & 11.3 & 11.3 \\
\hline 16.4 & $\mathrm{~F}$ & 925.9 & 33.5 & 167.3 & 8.7 & 7.4 \\
\hline 17.0 & $\mathrm{~F}$ & 419.8 & 24.2 & 290.1 & 11.5 & 12.7 \\
\hline 17.1 & $\mathrm{~F}$ & 2667.2 & 161.8 & 168.0 & 6.2 & 5.4 \\
\hline 18.0 & $\mathrm{~F}$ & 1677.0 & 83.8 & 172.9 & 9.0 & 6.4 \\
\hline 19.0 & $\mathrm{~F}$ & 1369.1 & 157.2 & 163.3 & 7.4 & 8.6 \\
\hline 19.2 & $\mathrm{~F}$ & 1151.4 & 82.2 & 181.7 & 4.3 & 6.8 \\
\hline 19.3 & $\mathrm{~F}$ & 795.5 & 65.0 & 263.9 & 10.2 & 10.2 \\
\hline 19.5 & $\mathrm{~F}$ & 1500.5 & 37.0 & 594.1 & 8.9 & 8.9 \\
\hline 19.7 & $\mathrm{~F}$ & 1807.3 & 133.7 & 227.1 & 7.9 & 6.9 \\
\hline 6.0 & $M$ & 414.4 & 19.8 & 152.2 & 9.9 & 9.9 \\
\hline 7.0 & $M$ & 325.3 & 11.9 & 93.8 & 7.1 & 9.5 \\
\hline 9.0 & $M$ & 283.1 & 21.1 & 132.2 & 8.2 & 10.5 \\
\hline 9.0 & $M$ & 455.5 & 21.1 & 186.2 & 9.4 & 8.2 \\
\hline 11.0 & $\mathrm{M}$ & 877.6 & 11.7 & 125.0 & 14.3 & 9.1 \\
\hline 11.0 & $M$ & 185.5 & 15.6 & 187.9 & 9.6 & 8.4 \\
\hline 12.0 & $M$ & 622.0 & 26.3 & 197.4 & 8.4 & 9.6 \\
\hline 12.0 & $M$ & 628.6 & 17.8 & 177.0 & 7.1 & 7.1 \\
\hline 12.5 & $M$ & 221.9 & 15.1 & 168.1 & 5.7 & 6.6 \\
\hline 13.3 & $M$ & 145.2 & 13.2 & 161.8 & 9.9 & 7.7 \\
\hline 13.7 & $M$ & 365.5 & 12.4 & 135.0 & 11.1 & 9.9 \\
\hline 13.8 & $M$ & 222.1 & 24.7 & 167.5 & 9.1 & 9.1 \\
\hline 13.9 & $M$ & 142.9 & 8.6 & 149.0 & 8.6 & 9.9 \\
\hline 13.9 & $M$ & 34.4 & 2.5 & 150.0 & 9.8 & 6.1 \\
\hline 14.1 & $M$ & 170.2 & 15.1 & 157.5 & 6.4 & 5.6 \\
\hline 14.2 & $M$ & 186.2 & 19.5 & 199.2 & 9.1 & 6.5 \\
\hline 14.7 & $M$ & 166.2 & 13.7 & 193.7 & 12.4 & 12.4 \\
\hline 15.0 & $M$ & 996.1 & 19.5 & 511.7 & 7.8 & 6.5 \\
\hline 15.0 & $M$ & 192.9 & 12.2 & 145.1 & 5.7 & 7.3 \\
\hline 15.1 & $M$ & 507.7 & 29.9 & 207.1 & 9.6 & 7.2 \\
\hline 15.7 & $M$ & 308.0 & 29.0 & 187.7 & 10.4 & 8.3 \\
\hline 15.7 & $M$ & 278.5 & 27.0 & 187.4 & 10.3 & 10.3 \\
\hline 15.9 & $M$ & 293.5 & 10.9 & 158.2 & 10.9 & 10.9 \\
\hline 16.2 & $M$ & 1151.8 & 61.4 & 303.3 & 9.8 & 9.8 \\
\hline 16.9 & $M$ & 135.4 & 11.4 & 136.2 & 6.1 & 7.0 \\
\hline 16.9 & $M$ & 166.3 & 14.3 & 182.5 & 10.5 & 5.7 \\
\hline 18.2 & $M$ & 836.7 & 33.2 & 182.5 & 6.1 & 7.0 \\
\hline 19.1 & $M$ & 126.1 & 16.0 & 162.2 & 7.6 & 6.7 \\
\hline 19.6 & $M$ & 357.0 & 26.8 & 216.7 & 8.9 & 8.9 \\
\hline
\end{tabular}


Concentration of each bioelement

\begin{tabular}{|c|c|c|c|c|c|c|c|c|c|}
\hline \multirow[b]{2}{*}{$\mathrm{Ca}$} & \multirow[b]{2}{*}{709.5} & \multirow[b]{2}{*}{575.4} & \multirow[b]{2}{*}{34.4} & \multirow[b]{2}{*}{2667.2} & \multicolumn{3}{|c|}{ Norm (Dunicz-Sokołowska) } & \multirow[b]{2}{*}{$\mathrm{Cu}$} & \multirow[b]{2}{*}{$\mathrm{Fe}$} \\
\hline & & & & & $\mathrm{Ca}$ & $\mathrm{Mg}$ & $\mathrm{Zn}$ & & \\
\hline $\mathrm{Mg}$ & 44.0 & 40.8 & 2.5 & 164.3 & 367.4 & 25.1 & 161.6 & 12.1 & 16.0 \\
\hline $\mathrm{Zn}$ & 204.8 & 86.0 & 93.8 & 594.1 & & & & & \\
\hline $\mathrm{Cu}$ & 10.5 & 6.8 & 4.3 & 54.2 & & & & & \\
\hline $\mathrm{Fe}$ & 10.4 & 5.1 & 5.4 & 30.6 & & & & & \\
\hline
\end{tabular}

cluding the ceruloplasmin concentration and superoxide dismutase activity (SOD1). SOD1 activity was found to significantly decrease with age. The study we performed was a one-time only event, and therefore cannot be used for comparison.

Analysis of $\mathrm{Zn}$ resources in children with the Down's syndrome (Lima et al., 2011) had shown low levels of $\mathrm{Zn}$. The obtained results could lead to a conclusion that changed nutritional status in individual patients with the Down's syndrome may be the reason for clinical disorders that occur with age. In our own research for the group of children with the Down's syndrome, we obtained normal $\mathrm{Zn}$ hair concentration for boys and a decreased level for girls.

Another study (Lech, 2002) had analyzed the lead $(\mathrm{Pb}), \mathrm{Cu}$ and $\mathrm{Mg}$ levels in the hair of 153 children and adolescents, aged 1-18, with selected neurological disorders. A significant decrease in the average hair $\mathrm{Mg}$ concentration was found and a slight increase in average $\mathrm{Cu}$ concentration. Both of the results obtained were statistically significant.

Table 2. Bioelements' concentration in the hair of boys with neurological disorders.

\begin{tabular}{|c|c|c|c|c|c|c|c|c|c|}
\hline & Mean & S.D. & Min & Max & & & & & \\
\hline \multicolumn{5}{|c|}{ Epilepsy } & \multicolumn{5}{|c|}{ Norm (Dunicz-Sokołowska) } \\
\hline $\mathrm{Ca}$ & 233.6 & 159.1 & 110.0 & 413.1 & $\mathrm{Ca}$ & $\mathrm{Mg}$ & $\mathrm{Zn}$ & $\mathrm{Cu}$ & $\mathrm{Fe}$ \\
\hline $\mathrm{Mg}$ & 18.6 & 4.6 & 15.7 & 23.9 & 296.2 & 21.3 & 159.5 & 12.4 & 15.5 \\
\hline $\mathrm{Zn}$ & 172.4 & 11.1 & 164.5 & 185.0 & & & & & \\
\hline $\mathrm{Cu}$ & 7.0 & 1.8 & 5.0 & 8.6 & & & & & \\
\hline $\mathrm{Fe}$ & 11.2 & 3.6 & 7.1 & 13.8 & & & & & \\
\hline \multicolumn{5}{|c|}{ Down's syndrome } & \multicolumn{5}{|c|}{ Norm (Dunicz-Sokołowska) } \\
\hline $\mathrm{Ca}$ & 139.0 & 24.2 & 0.0 & 0.0 & $\mathrm{Ca}$ & $\mathrm{Mg}$ & $\mathrm{Zn}$ & $\mathrm{Cu}$ & $\mathrm{Fe}$ \\
\hline $\mathrm{Mg}$ & 13.7 & 3.9 & 8.9 & 20.4 & 292.5 & 20.8 & 154.0 & 12.0 & 15.8 \\
\hline $\mathrm{Zn}$ & 164.6 & 29.1 & 136.8 & 226.6 & & & & & \\
\hline $\mathrm{Cu}$ & 8.6 & 2.6 & 6.4 & 13.7 & & & & & \\
\hline $\mathrm{Fe}$ & 11.9 & 5.5 & 8.3 & 24.7 & & & & & \\
\hline \multicolumn{5}{|c|}{ Cerebral palsy } & \multicolumn{5}{|c|}{ Norm (Dunicz-Sokołowska) } \\
\hline $\mathrm{Ca}$ & 372.3 & 284.1 & 34.4 & 1151.8 & $\mathrm{Ca}$ & $\mathrm{Mg}$ & $\mathrm{Zn}$ & $\mathrm{Cu}$ & $\mathrm{Fe}$ \\
\hline $\mathrm{Mg}$ & 19.4 & 10.8 & 2.5 & 61.4 & 292.5 & 20.8 & 154.0 & 12.0 & 15.8 \\
\hline $\mathrm{Zn}$ & 183.2 & 73.3 & 93.8 & 511.7 & & & & & \\
\hline $\mathrm{Cu}$ & 9.0 & 2.0 & 5.7 & 14.3 & & & & & \\
\hline $\mathrm{Fe}$ & 8.3 & 1.7 & 5.6 & 12.4 & & & & & \\
\hline \multicolumn{5}{|c|}{ Sum } & \multicolumn{5}{|c|}{ Norm (Dunicz-Sokołowska) } \\
\hline $\mathrm{Ca}$ & 315.2 & 262.0 & 34.4 & 1151.8 & $\mathrm{Ca}$ & $\mathrm{Mg}$ & $\mathrm{Zn}$ & $\mathrm{Cu}$ & $\mathrm{Fe}$ \\
\hline $\mathrm{Mg}$ & 18.2 & 9.6 & 2.5 & 61.4 & 292.5 & 20.8 & 154.0 & 12.0 & 15.8 \\
\hline $\mathrm{Zn}$ & 178.7 & 63.9 & 93.8 & 511.7 & & & & & \\
\hline $\mathrm{Cu}$ & 8.7 & 2.1 & 5.0 & 14.3 & & & & & \\
\hline $\mathrm{Fe}$ & 9.3 & 3.3 & 5.6 & 24.7 & & & & & \\
\hline
\end{tabular}


Table 3. Bioelements' concentration in the hair of girls with neurological disorders.

\begin{tabular}{|c|c|c|c|c|c|c|c|c|c|}
\hline \multirow{2}{*}{\multicolumn{2}{|c|}{ Epilepsy }} & SD & Min & \multicolumn{6}{|l|}{ Max } \\
\hline & & & & & \multicolumn{5}{|c|}{ Norm (Dunicz-Sokołowska) } \\
\hline $\mathrm{Ca}$ & 972.1 & 207.6 & 649.6 & 1172.5 & $\mathrm{Ca}$ & $\mathrm{Mg}$ & $\mathrm{Zn}$ & $\mathrm{Cu}$ & $\mathrm{Fe}$ \\
\hline $\mathrm{Mg}$ & 67.6 & 24.7 & 38.4 & 98.2 & 594.3 & 39.2 & 193.7 & 12.9 & 16.1 \\
\hline $\mathrm{Zn}$ & 234.0 & 76.1 & 179.8 & 385.6 & & & & & \\
\hline $\mathrm{Cu}$ & 24.4 & 18.9 & 9.2 & 54.2 & & & & & \\
\hline $\mathrm{Fe}$ & 18.8 & 6.0 & 11.3 & 28.0 & & & & & \\
\hline \multicolumn{5}{|c|}{ Down's syndrome } & \multicolumn{5}{|c|}{ Norm (Dunicz-Sokołowska) } \\
\hline $\mathrm{Ca}$ & 692.4 & 362.0 & 0.0 & 0.0 & $\mathrm{Ca}$ & $\mathrm{Mg}$ & $\mathrm{Zn}$ & $\mathrm{Cu}$ & $\mathrm{Fe}$ \\
\hline $\mathrm{Mg}$ & 33.5 & 13.5 & 13.1 & 57.3 & 450.7 & 30.1 & 171.8 & 12.3 & 16.3 \\
\hline $\mathrm{Zn}$ & 198.9 & 69.5 & 102.6 & 339.5 & & & & & \\
\hline $\mathrm{Cu}$ & 12.5 & 6.0 & 7.1 & 25.3 & & & & & \\
\hline $\mathrm{Fe}$ & 14.6 & 8.9 & 7.2 & 30.6 & & & & & \\
\hline \multicolumn{5}{|c|}{ Cerebral palsy } & \multicolumn{5}{|c|}{ Norm (Dunicz-Sokołowska) } \\
\hline $\mathrm{Ca}$ & 1262.2 & 571.7 & 419.8 & 2667.2 & $\mathrm{Ca}$ & $\mathrm{Mg}$ & $\mathrm{Zn}$ & $\mathrm{Cu}$ & $\mathrm{Fe}$ \\
\hline $\mathrm{Mg}$ & 82.4 & 47.9 & 21.3 & 164.3 & 450.7 & 30.1 & 171.8 & 12.3 & 16.3 \\
\hline $\mathrm{Zn}$ & 240.6 & 109.9 & 140.6 & 594.1 & & & & & \\
\hline $\mathrm{Cu}$ & 9.3 & 2.0 & 4.3 & 13.5 & & & & & \\
\hline $\mathrm{Fe}$ & 8.5 & 1.9 & 5.4 & 12.7 & & & & & \\
\hline \multicolumn{5}{|c|}{ Summary } & \multicolumn{5}{|c|}{ Norm (Dunicz-Sokołowska) } \\
\hline $\mathrm{Ca}$ & 1085.1 & 541.0 & 176.9 & 2667.2 & $\mathrm{Ca}$ & $\mathrm{Mg}$ & $\mathrm{Zn}$ & $\mathrm{Cu}$ & $\mathrm{Fe}$ \\
\hline $\mathrm{Mg}$ & 68.6 & 44.0 & 13.1 & 164.3 & 450.7 & 30.1 & 171.8 & 12.3 & 16.3 \\
\hline $\mathrm{Zn}$ & 229.7 & 97.2 & 102.6 & 594.1 & & & & & \\
\hline $\mathrm{Cu}$ & 12.2 & 9.0 & 4.3 & 54.2 & & & & & \\
\hline $\mathrm{Fe}$ & 11.4 & 6.3 & 5.4 & 30.6 & & & & & \\
\hline
\end{tabular}

The $\mathrm{Fe}, \mathrm{Cu}$ and $\mathrm{Mg}$ concentrations in Kalra's et al. study were found to be relevantly low in children with cerebral palsy, which justified the need of supplementation (Kalra, 2015). In our research, in all groups we had found low concentrations of $\mathrm{Fe}$, both, for the girls and the boys.

Multivariate analysis of the selected metals in the hair of cerebral palsy patients in comparison to healthy control group, performed by Khalique et al. (2006), had shown a significant influence in the affected patients' physiology.

In the study presented above, we have analyzed the concentrations of selected bioelements in the hair of children with certain neurological disorders. The analyses performed show an abnormal (high or low) bioelement concentrations in hair, however they are not comparable to the serum levels because the two- hair and serum make different compartments.

As a point of reference for our research, we have used a group of 7400 children and young adults who had 5 basic bioelements and oxic metals determined by hair analysis in a study that could be considered as a referential norm in the hair of Polish population (Dunicz-Sokolowska, 2006; Dunicz-Sokolowska, 2006).

\section{CONCLUSIONS}

1. Analysis of the selected bioelements in the hair of patients with epilepsy, Down's syndrome and cerebral palsy has shown differentiated results.

2. The assessment of concentrations of these bioelements only in the hair of the studied group, without simultaneous analysis of the blood serum levels, does not indicate the need for bioelement supplementation in the patients with selected neurological disorders.

\section{REFERENCES}

Aggett PJ (1985) Physiology and metabolism of essential trace elements: an outline. Clin Endocrinol Metab 14: 513-543

Amouian S, Mohammadian S, Behnampour N, Tizrou M (2013) Trace elements in febrile seizure compared to febrile children admitted to an academic hospital in Iran, 2011. J Clin Diagn Res 7: 2231-2233. https://doi.org/10.7860/JCDR/2013/5548.3478

Dunicz-Sokolowska A, Graczyk A, Radomska K, Długaszek M, Wlaźlak E, Surkont G(2006) Contents of bioelements and toxic metals in a Polish population determined by hair analysis Part 2. Young persons aged 10-20 years. Magnes Res 19: 167-79, https:// doi.org/10.1684/mrh.2006.0004

Dunicz-Sokolowska A, Radomska K, Długaszek M, Graczyk A (2006) Contents of bioelements and toxic metals in Polish population de- 
termined by hair analysis. Populational studies. Part I. Children aged 1 to 10 years. Magnes Res 19: 35-45

Fung EB (2002) Feeding dysfunction is associated with poor growth and health status in children with cerebral palsy. I Am Diet Assoc 102: 361-368. https://doi.org/10.1016/S0002-8223(02)90084-2

Gajewska E (2009) The new definitions and functional scales used in children with cerebral palsy. Child Neurology 18: 67-72

Hartley H (2003) Current practice in the management of children with cerebral palsy: a national survey of paediatric dietitian. J Hum Nutr Diet 16: 219-224. https://doi.org/10.1046/j.1365-277X.2003.00452.x

Kalra S, Aggarwal A, Chillar N, Faridi MM (2015)Comparison of micronutrient levels in children with cerebral palsy and neurologically normal controls. Indian J Pediatr 82: 140-144. https://doi. org/10.1007/s12098-014-1543-z

Khalique A, Shah MH, Jaffar M, Shaheen N, Tariq SR, Manzoor S (2006) Multivariate analysis of the selected metals in the hair of cerebral palsy patients versus controls. Biol Trace Elem Res 111: 11-22. https://doi.org/10.1385/BTER:111:1:11

Kheradmand Z, Yarali B, Zare A, Pourpak Z, Shams S, Ashrafi MR (2014) Comparison of serum zinc and copper levels in children and adolescents with intractable and controlled epilepsy. Iran J Child Neurol 8: 49-54

Kilpinen-LoisaP (2009) Insufficient energy and nutrient intake in children with motor disability. Acta Paediatr 8: 1329-1333. https://doi. org/10.1111/j.1651-2227.2009.01340.x

Lech T (2002) Lead, copper, zinc and magnesium content in hair of children and young people with some neurological diseases. Biol Trace Elem Res 85: 111-126. https://doi.org/10.1385/BTER:85:2:111

Lima AS, Cardoso BR, Cozzolino SF (2010) Nutritional status of zinc in children with Down syndrome. Biol Trace Elem Res 133: 20-28. https://doi.org/10.1007/s12011-009-8408-8

Maathuis FJ (2009) Physiological functions of mineral macronutrients. Curr Opin Plant Biol 12: 250-258. https://doi.org/10.1016/j. pbi.2009.04.003
Macioszczyk A (1987) Hydrogeochemistry. pp 97-99. Geological Publishers, Warsaw

Prasad DK, Shaheen U, Satyanarayana U, Surya Prabha T, Jyothy A, Munshi A (2014) Association of serum trace elements and minerals with genetic generalized epilepsy and idiopathic intractable epilepsy. Neurochem Res 39: 2370-2376. https://doi.org/10.1007/s11064-0141439-3

Rodwell V, Bender D, Botham KM, Kennelly PJ, Weil PA (2015) Harper's Illustrated Biochemistry. 30th edn. Mcgraw-Hill Education Ltd, New York

Roizen NJ, Patterson D (2003) Down's syndrome. Lancet 361: 12811289

Saad K, El-Houfey AA, Abd El-Hamed MA, El-Asheer OM, Al-Atram AA, Tawfeek MS (2015) A randomized, double-blind, placebo-controlled clinical trial of the efficacy of treatment with zinc in children with intractable epilepsy. Funct Neurol 30: 181-185

Saghazadeh A, Mahmoudi M, Meysamie A, Gharedaghi M, Zamponi GW, Rezaei N (2015) Possible role of trace elements in epilepsy and febrile seizures: a meta-analysis. Nutr Rev 73: 760-779. doi: 10.1093 /nutrit/nuv026

Thurman DJ, Beghi E, Begley CE, Berg AT, Buchhalter JR, Ding D, Hesdorffer DC, Hauser WA,Kazis L, Kobau R, Kroner B, Labiner D, Liow K, Logroscino G, Medina MT, Newton CR, Parko K, Paschal A, Preux PM, Sander JW, Selassie A, Theodore W, Tomson T, Wiebe S; ILAE Commission on Epidemiology (2011) Standards for epidemiologic studies and surveillance of epilepsy. Epilepsia 7: 2-26. https://doi.org/10.1111/j.1528-1167.2011.03121.x

Tórsdóttir G,Kristinsson J, Hreidarsson S, Snaedal J, Jóhannesson T (2001) Copper, ceruloplasmin and superoxide dismutase (SOD1) in patients with Down's syndrome. Pharmacol Toxicol 89: 320-325. https://doi.org/10.1034/j.1600-0773.2001.d01-168.x 